American Klezmer 
This page intentionally left blank 


\section{American Klezmer}

Its Roots and Offshoots

Edited by

Mark Slobin

UNIVERSITY OF CALIFORNIA PRESS

Berkeley · Los Angeles · London 
Chapter 6 was originally published in Ethnomusicology 38: I (Winter I994). Copyright I994 by the Board of Trustees of the University of Illinois. Used with the permission of the University of Illinois Press.

Chapter 8 was adapted from Henry Sapoznik, Klezmer!: Jewish Music from Old World to Our World (New York: Schirmer Books, I999).

University of California Press

Berkeley and Los Angeles, California

University of California Press, Ltd.

London, England

(C) 2002 by the Regents of the University of California

Library of Congress Cataloging-in-Publication Data

American Klezmer : its roots and offshoots / edited by Mark Slobin

p. $\quad \mathrm{cm}$.

Includes bibliographical references and index. ISBN 0-520-227 I7-4 (cloth: alk. paper)ISBN 0-520-227I 8-2 (pbk. alk. paper)

I. Klezmer music-Congresses. 2. JewsMusic-Congresses. I. Slobin, Mark.

II. Klezmer Research Conference (Ist : I996 : Wesleyan University)

ML3528.8 .K54 2002

$781.62^{\prime} 924-\mathrm{dc} 2 \mathrm{I}$

O०-05 I I 68

CIP

MN

Manufactured in the United States of America
$\begin{array}{llllllllll}10 & 09 & 08 & 07 & 06 & 05 & 04 & 03 & 02 & \text { OI }\end{array}$
$\begin{array}{llllllllll}\text { IO } & 9 & 8 & 7 & 6 & 5 & 4 & 3 & 2 & \text { I }\end{array}$

The paper used in this publication meets the minimum requirements of ANSI/NISO Z39.48-I992 (R I997) (Permanence of Paper).@) 